\title{
Inheritance of resistance to Cercospora leaf spot disease of cowpea [Vigna unguiculata (L.) Walp]
}

\author{
Lucky O. Omoigui - Matilda O. Arrey • Alpha Y. Kamara - Catherine C. Danmaigona • \\ Godspower Ekeruo $\cdot$ Michael P. Timko
}

Received: 22 May 2018/ Accepted: 12 April 2019/Published online: 3 May 2019

(C) The Author(s) 2019

\begin{abstract}
Cercospora leaf spot (CLS) caused by Pseudocercospora cruenta (Sacc.) is an important disease affecting cowpea production in Nigeria. Understanding the genetic nature of CLS is an important step in developing an effective breeding strategy. This study investigated the inheritance of CLS disease in cowpea under natural epiphytotic field condition involving two CLS resistant parents (IT99K-573-1-1, IT99K216-24) and a CLS susceptible parent (UAM09-1055-6). The parental lines, $\mathrm{F}_{1}$, $\mathrm{BC}_{1} \mathrm{P}_{1}, \mathrm{BC}_{1} \mathrm{P}_{2}, \mathrm{~F}_{2}$ and $\mathrm{F}_{3}$ generations were used to study the genetic nature and to detect SSR markers closely linked with the CLS resistance gene(s) using bulked segregant analysis (BSA). The result showed that $F_{1}$ populations involving UAM09-1055-
\end{abstract}

L. O. Omoigui $(\bowtie) \cdot$ M. O. Arrey ·

C. C. Danmaigona - G. Ekeruo

Department of Plant Breeding and Seed Science, College

of Agronomy, University of Agriculture,

P.M.B. 2373, Makurdi, Nigeria

e-mail: luckyomoigui@gmail.com;

1.omoigui@cgiar.org

Present Address:

L. O. Omoigui · A. Y. Kamara

International Institute of Tropical Agriculture (IITA), Ibadan, Nigeria, c/o IITA LTD, Grosvenor House, 125 High Street,

Croydon CR09XP, UK

M. P. Timko

Department of Biology, University of Virginia,

Charlottesville, USA
$6 \times$ IT99K-573-1-1 and UAM09-1055-6 × IT99K216-24 were resistant to CLS in the 2 crosses suggesting the presence of gene dominance in the control of the disease. The observed segregating ratio of $F_{2}$ populations fits the Mendalian ratio 3:1. The plants reaction to the disease in the backcross progeny test involving the resistant parent were all uniformly resistant, whereas those involving the susceptible parent segregated into ratio $1: 1$. The $\mathrm{F}_{3}$ generations, which segregated into ratio 1:2:1 further confirmed that resistance was controlled by a single dominant gene in the crosses studied. Heritability estimates varied from 81 to $97 \%$. BSA showed that SSR marker code named RB24 of lima bean and validated on $\mathrm{F}_{2}$ population discriminated between resistance and susceptibility to CLS. Hence RB24 could be a useful marker for marker-assisted selection in CLS resistance breeding in cowpea.

Keywords Cowpea - Cercospora leaf spot disease . Resistant $\cdot$ Susceptible $\cdot$ SSR marker

\section{Introduction}

Cowpea [Vigna unguiculata (L.) Walp.] is one of the most important food legumes of vital importance to the livelihoods of millions of people in West and Central Africa (WCA). Cowpea seeds and young leaves have high protein contents (over 25\% on dry 
weight basis), therefore, cowpea is a major source of protein, minerals and vitamins for human and livestock nutrition (Singh et al. 2003) in WCA. Cowpea hay is also valued as a balanced nutrition fodder and it is sold in local markets for animal feed especially during the dry season in WCA (Tarawali et al. 2002).

Approximately $90 \%$ of world's cowpea is grown in sub-Saharan Africa, mostly in Nigeria and Niger. According to FAOSTAT (2017), cowpea was grown on about 12.3 million ha of land globally and 6.9 million tons of grain was produced. Nigeria, the largest cowpea producer in the world accounts for about 3 million tons of the world production from a cultivated land area of 3.5 million ha. Cowpea is mainly cultivated under traditional farming systems and grain yields in farmers' fields are low due to numerous problems including insect pests and diseases, parasitic weeds and environmental stresses, which are major production constraints.

Cowpea diseases are induced by several pathogenic organisms including viruses, bacteria, fungi, protozoa and worms. One of such fungal foliar diseases that has been reported to cause severe yield loss in cowpea is the Cercospora leaf spot disease caused by two fungi namely; Cercospora canescens Ellis and Martin, and Pseudocercospora cruenta (Sacc.) Deighton (formerly Cercospora cruenta) (Allen and Lenne 1998). Both pathogens survive the no-crop period on infected crop residue and in infected seed (Schneider et al. 1976). Cercospora leaf spot (CLS), incited by the fungus Pseudocercospora cruenta (Sacc.), is the most widespread and most destructive disease of cowpea in the Northern and Guinea savanna zones of Nigeria (Allen 1983). Most of the CLS damage occurs late in the growing season when the crop's vegetative and reproductive parts are fully developed. The disease attacks the leaves causing a serious yield loss because of severe defoliation. Yield loss up to $40 \%$ due to infection has been reported (Schneider et al. 1976). Crop diseases do not only reduce grain yield but can impair the fodder quality, and consequently undermine efforts to promote crop-livestock integration. Emphasis on cowpea improvement has centred on grain yield with little attention on the fodder quality. The major constraint to livestock production in Nigeria today is fodder deficiency especially during dry season when pasture vegetation is dry. Availability of quality cowpea hay/fodder is important to sustain livestock production through the year, so breeding for cowpea varieties that produces high-quality (diseasefree) and improved fodder yield is important to meet the demand for livestock feed.

CLS is encountered during the rainy season of relatively hot and high humid conditions (Poehlman 1991). The fungus has a wide host range, attacking other legumes such as common beans (Phaseolus), soybean and bambara groundnut. These alternative hosts extend the reservoir of plants which can carry over infections to the next growing season. The disease symptom on infected plants presents necrotic spots on the upper leaf surface and profuse masses of conidiophores and conidia, appearing as downy grey to black mats, on the lower leaf surface. The symptom of the disease is not apparent until the time of flowering but can rapidly progress acropetally leading to premature defoliation. Severe infections have also been reported to result in lesions developing on pods and stems (Mulder and Holliday 1975a; Hart 1977). The outward symptoms typically become evident during flowering and early pod development, resulting in significant yield loss. CLS disease is seed borne and seed transmitted (Schneider et al. 1976).

Because the CLS has a wide host range, it is difficult to manage through fungicide applications alone. Continuous use of fun-gicides results in detrimental effects on the environment and development of resistant strains of the pathogen. Also, the Chlamydospore that form thick walled asexual spores can survive in infected debris on a wide range of alternate host. These factors make crop rotation an incomplete control measure. The use of fungicide on the other hand, not only increases cost of production but are hazardous to man and are beyond the reach of smallholder farmers, who are the major producers of this crop. Therefore, the most effective means to control economic losses from CLS is breeding of cowpea varieties with genetic resistance to the disease. Thus, the development and deployment of cowpea varieties with resistance to CLS is the most cost effective and economically friendly approach to combat the disease. Despite the devastating effects of the pathogen, breeding program towards the development of CLS resistant cowpea cultivars has been minimal in Nigeria.

To develop an effective breeding strategy for the introgression of CLS resistance genes in cowpea, a detailed knowledge of the nature of inheritance pattern of disease in the host will be useful. Although, 
numerous sources of resistance to CLS have been identified in other crops (Mukesh et al. 2017; Duangsong et al. 2018), limited information is available on the genetic basis of inheritance of this disease in cowpea. From available literature, genetic basis of CLS resistance has been characterized as qualitative, determined by either dominant, co-dominant or recessive genes, depending on the cross (Castro et al. 2003). Kimber and Paull (2011) studied the genetics of resistance to Cercospora leaf spot in Feba bean and reported a monogenic dominant gene control leaf spot resistance with resistance dominant over susceptibility. Pasupuleti et al. (2013) reported that late leaf spot in groundnut was governed by a combination of both, nuclear and maternal gene effects. Little or no information is available on the genetics of CLS resistance in Nigerian cowpea varieties. There is a clear need for such knowledge on genetics of resistance to CLS that will enable breeders to design an efficient breeding strategy to improve the local germplasm.

Conventional breeding often requires a decade or more to develop and release a new cowpea cultivar because it involves screening and identifying appropriate resistant germplasm sources and then introgressing the resistance trait. Molecular tools, including marker-assisted selection, have the potential to accelerate and improve the effectiveness of breeding for disease resistance in many crops. For this reason, during the last decade, substantial efforts have been made on screening and identification of linked markers for important diseases of cowpea. Identification and use of linked markers could reduce the length of breeding time by less than half the conventional breeding time. Molecular genetic tools and genomic resources have been developed for cowpea with an objective of expediting breeding programs for the improvement of cowpea varieties in Nigeria and numerous countries in Africa. DNA molecular markers are becoming a research hotspot: Various markers like RFLP, RAPD, AFLP, SSR and SNP have been employed in several studies. Microsatellite (SSR) markers have been successfully used for markerassisted selection in many crops including cowpea breeding for different constraints. For example, Molecular markers linked to $S$. gesnerioides racespecific resistance genes in cowpea have been reported in different studies. Ouedraogo et al. (2001, 2002); identified three AFLP markers that are tightly linked to the gene designated $R s g 2-1$ which confers resistance to Race 1 of $S$. gesnerioides in Burkina Faso. Similarly, Diouf and Hilu (2005), Ogunkanmi et al. (2008) reported SSR markers for genetic diversity in wild relatives of cowpea. Several other SSR markers have been reported to be linked to other biotic stresses. For example, Fusarium resistance (Pottorff et al. 2012; Omoigui et al. 2018), early and late leaf spot in groundnut (Shoba et al. 2012; Zongo et al. 2017) and Striga resistance in cowpea (Boukar et al. 2004).

Some promising markers have been identified and tested in this study (UVA cowpea group, unpublished data). A set of cowpea SSR primer combinations based on cowpea gene space read (GSR) sequences annotated for disease and pest resistance genes (Timko et al. 2008) were downloaded from the Cowpea Genomics Knowledge Base (CGKB) (http:// cowpeagenomics.med.virginia.edu/CGKB) website. Over 2000 SSR markers were initially screened for amplification and polymorphism using susceptible and resistant parental lines to identify closely linked markers for CLS disease of cowpea. Based on the screening, we identified RB24 primer that showed polymorphism with the disease. The marker was further validated using bulk segregant analysis (BSA) and genotyping $F_{2}$ population for its efficacy. This prompted us to characterize the parental materials for resistance to CLS using this marker with a goal of establishing a marker-assisted selection (MAS) system for resistance to this disease.

The objective of the present study was to (1) determine the mode of inheritance of CLS resistance in cowpea and (2) test the applicability of previously identified molecular marker in genotyping segregating population to distinguish the resistant and susceptible individuals for CLS.

\section{Materials and methods}

\section{Plant material}

Two CLS resistant cowpea cultivars namely, IT99K573-1-1 and IT99K-216-44 were selected from our previous studies (not published) based on their reaction to CLS and one susceptible cultivar, UAM-091055-6, were used as parents in this study (Table 1). The three parental cultivars were further phenotyped in the screenhouse at the University of Agriculture 
Table 1 Parental cowpea genotypes used to produce hybrid populations and their reaction to Cercospora leaf spot

\begin{tabular}{|c|c|c|c|c|c|}
\hline $\begin{array}{l}\mathrm{S} / \\
\mathrm{N}\end{array}$ & Genotype & Source & Characteristics features & Pedigree & $\begin{array}{l}\text { Reaction to } \\
\text { Cercospora leaf } \\
\text { spot }\end{array}$ \\
\hline 1 & $\begin{array}{l}\text { IT99K- } \\
573-1-1\end{array}$ & IITA & $\begin{array}{l}\text { Medium maturing with erect growth habit, white flower, highly } \\
\text { resistant to Striga and Alectra, and tolerant to drought. long pod } \\
\text { containg medium sized white seed }\end{array}$ & $\begin{array}{l}\text { IT93K-596-9- } \\
\text { 12/IT86D- } \\
880\end{array}$ & $\mathrm{R}$ \\
\hline 2 & $\begin{array}{l}\text { IT99K- } \\
216-44\end{array}$ & IITA & $\begin{array}{l}\text { Improved line. Early maturing with twining growth habit, Purple } \\
\text { flower, Suscepible to Striga, long hairy pod containing medium } \\
\text { sized white seed }\end{array}$ & $\mathrm{n} / \mathrm{a}$ & $\mathrm{R}$ \\
\hline 3 & $\begin{array}{r}\text { UAM09- } \\
1055-6\end{array}$ & UAM & $\begin{array}{l}\text { Early maturing with white flowers, highly resistant to Striga and } \\
\text { Alectra, long pod containg medium sized white seeds }\end{array}$ & $\begin{array}{l}\text { Borno local/ } \\
\text { IT97K-499- } \\
35\end{array}$ & $S$ \\
\hline
\end{tabular}

$R$ resistant, $S$ suceptible; $n / a$ not available, UAM University of Agriculture, Makurdi, IITA International Institute of Tropical Agriculture

Makurdi in 2017 and the results validated using previously identified associated SSR marker.

Population development

The two best resistant cultivars (IT99K-573-1-1, IT99K-216-44) were crossed with the susceptible parent (UAM09-1055-6). Emasculation and pollination were done either in the morning or in the evening when the temperature is low, and humidity is high to obtain maximum success. Matured pods resulting from successful crossing were harvested at maturity for $F_{1}$ seeds generation and resulting $F_{1}$ plants were grown in the screenhouse and selfed to produce the $F_{2}$ generations. Then $F_{2}$ plants were self-pollinated to produce $\mathrm{F}_{3}$ progenies. The $\mathrm{F}_{1}$ 's were backcrossed to each parent to produce $\mathrm{BC}_{1} \mathrm{P}_{1}$ and $\mathrm{BC}_{1} \mathrm{P}_{2}$ generations, respectively.

Field screening establishment

The test materials $\left(\mathrm{F} 1 / \mathrm{F} 2 / \mathrm{F} 3, \mathrm{BC}_{1} \mathrm{P}_{1}\right.$ and $\left.\mathrm{BC}_{1} \mathrm{P}_{2}\right)$ were evaluated for their reaction to CLS disease in an artificially induced epiphytotic field condition attained using spreader row-method as described by Booker and Umaharan (2007). The experimental materials were established on row plot measuring $4 \mathrm{~m}$ long, with an inter-row spacing of $0.75 \mathrm{~m}$ and intra-row spacing of $0.2 \mathrm{~m}$. The parents and progenies were assigned to each plot consisting of a single test row, 4-m long for each of the parent, two rows for $F_{1}$ hybrids and backcross populations, and eight rows for $F_{2}$ populations arranged in a randomized complete block design with three replications. The $F_{3}$ families consisted of two row plot each. Each plot as well as the block were surrounded by a susceptible spreader row (UAM09-1055-6), planted two weeks in advance of the test varieties to serve as checks and to assist in ensuring adequate inoculum development. The spreader rows were inoculated at the flower initiation stage of the crop with a diseased leaf wash (10 $\mathrm{g}$ leaf: $1 \mathrm{~g}$ $\mathrm{H}_{2} 0 ; 4.8 \times 10^{5}$ conidia $\mathrm{ml} ; 14 \mathrm{mls}$ plant $^{-1}$ ). The inoculum was applied to the plants with a knapsack sprayer until runoff. In addition, diseased leaf debris was placed at the base of spreader plants. After inoculation, water spray was applied to spreader row plants in the evening to maintain high humidity for disease development. Two seeds of the test materials $\left(\mathrm{F}_{1}, \mathrm{~F}_{2}, \mathrm{~F}_{3}, \mathrm{BC}_{1} \mathrm{P}_{1}\right.$ and $\left.\mathrm{BC}_{1} \mathrm{P}_{2}\right)$ were sown per hole. Pre-emergence herbicide application of Pendimethalin at $1 \mathrm{~kg}$ active ingredient per ha was applied immediately after planting. All recommended package of practices was adopted to raise a healthy crop that included, $30 \mathrm{~kg} / \mathrm{ha} \mathrm{P}_{2} \mathrm{O}_{5}$ and $10 \mathrm{~kg} / \mathrm{ha}$ NPK granular fertilizer applied at two weeks after planting. Protection against insect pests was controlled by spraying Cypermethrine + Dimethoate at the rate of $50 \mathrm{~g}$ a.i/ ha. Weeds were controlled manually using hoe, first at 3 weeks after planting, second at 6-7 weeks after planting. The different generation of progenies $\left(\mathrm{F}_{1}\right.$, $\mathrm{BC}_{1} \mathrm{P}_{1}, \mathrm{BC}_{1} \mathrm{P}_{2}, \mathrm{~F}_{2}$ and $\mathrm{F}_{3}$ from the two populations along with their two parents were phenotyped in a replicated trial for resistance to CLS. 
Disease evaluation

Observations on disease score, defoliation percentage and leaf area damage (LAD) at 78, 89 and 104 days after sowing (DAS) were recorded on each plant in each generation. A 5-point scale, as described by Oladiran and Oso (1983), was followed to record disease severity in the field. Where $0=$ No spot-on leaf, $1=1-10 \%$ leaf lamina covered by spots, $2=11-25 \%$ leaf lamina covered by spots, $3=26-50 \%$ leaf lamina covered by spots, $4=51-75 \%$ leaf lamina covered by spots and $5=76 \%$ and above leaf lamina covered by spots. Final evaluation of the symptoms based on susceptible or resistant reactions was performed on individual plants at 63 days after planting

Identification of marker linked to disease resistance gene

\section{DNA extraction and amplification}

Following field phenotyping of the parental materials, DNA analysis was carried out to validate phenotypic data using bulked segregant analysis. Bulked segragants analysis were done to identify the markers' linked to CLS. Ten randomly selected plants from the homozygous resistant and homozygous susceptible $\mathrm{F}_{2}$ plants were used to prepare separate bulk. Young leaves of 14-day old plantlets were collected from parents and individuals of the segregating population. DNA extraction was performed using the FTA $^{\circledR}$ PlantSaver cards as described by Omoigui et al. (2012). The extracted DNA of the 10 most resistant and 10 most susceptible materials were bulked separately by pooling aliquots containing $50 \mathrm{ng} / \mu \mathrm{l}$ from each susceptible and resistant $\mathrm{F}_{2}$-selected plants. PCR was carried out on the bulks and parental DNA samples using SSR primers. PCR reaction mixture was performed in a total volume of $20 \mu$ for PCR reaction using customized Accupower PCR premix tube (BIONEER) to which a purified FTA disc containing the DNA sample and $16(\mu \mathrm{l})$ of water-Molecular Biology Grade (Lonza) were added. The PCR profile of SSR followed was used: one cycle of $95{ }^{\circ} \mathrm{C}$ for $4 \mathrm{~min}$; followed by 44 cycles of $95^{\circ} \mathrm{C}$ for $1 \mathrm{~min}$; $55{ }^{\circ} \mathrm{C}$ for $30 \mathrm{~s} ; 72{ }^{\circ} \mathrm{C}$ for $30 \mathrm{~s}$ of 35 cycles with a final extension at $72{ }^{\circ} \mathrm{C}$ for $2 \mathrm{~min}$ and held for $4{ }^{\circ} \mathrm{C}$ for infinity.

PCR amplification was performed with the BIORAD MyCycler TM thermal cycler. Amplified products from SSR markers were separated on $2 \%$ agarose gels stained with ethidium bromide $(10 \mathrm{ng} / 100 \mathrm{ml}$ solution in Tris-EDTA buffer).

Data collection and analysis

Data was collected on the following:

"Reaction of individual plants to CLS (Present or Absent), Days to disease incidence: this was done on daily basis, Number of infected leaves/nodes (average lesion count on five disease leaves per plant), Disease severity (taken at 7,8 and 9 weeks after planting" Square root transformation was applied of values that include 0 for statistical analyses.

The analysis of phenotypic data (disease severity scores) was performed in SAS system for Window (SAS Institute 2014). Means were separated using least significant difference (LSD) at $5 \%$ probability level.

\section{Genetic analysis}

Segregation ratios were analysed using a Chi square test. The individuals from the crosses that were scored as resistant and susceptible in the progeny populations were subjected to Chi square test for goodness of fit to test deviation from the theoretical expected Mendalian segregation ratios for $\mathrm{F}_{1}, \mathrm{BC}_{1} \mathrm{P}_{1} \mathrm{~F}_{1}, \mathrm{BC}_{1} \mathrm{P}_{2} \mathrm{~F}_{1}, \mathrm{~F}_{2}$ and $\mathrm{F}_{3}$ from populations (UAM-09-1055-6 $\times$ IT99K-573-11) and (UAM-09-1055-6 $\times$ IT99K-216-44). The genetic distance between SSR markers and the CLS resistance gene was determined in QTL IciMapping ver. 4.1 (http://www.isbreeding.net) using the Kosambi mapping function. Mapping parameters consisted of LOD 3.0 and Two Opt algorithm.

Heritability, in its broad-sense, was estimated, according to Warner (1952), as follows:

$h^{2}=\frac{\mathrm{v}_{\mathrm{G}}}{\mathrm{v}_{p}} \times 100$

where $h^{2}=$ broad-sense heritability; $\mathrm{V}_{p}=$ phenotypic variance of $\mathrm{F}_{2}$ individuals $\left(\mathrm{V}_{\mathrm{F} 2}\right)$ and $\mathrm{V}_{G}=$ Genotypic variance of $\mathrm{F} 2$ individuals $\left[\mathrm{V}_{F 2}-\frac{1}{3}\left(\mathrm{~V}_{F 1}+\mathrm{V}_{p 1}+\mathrm{V}_{p 2}\right)\right]$ 


\section{Results and discussion}

Phenotypic analysis

The two parents showed contrasting reaction to the disease when inoculated with the pathogen isolate. The incidence of CLS disease on the leaves of the susceptible parents UAM 09-1055-6 was 100\% of the leaf area being covered by lesions in the experiments. In contrast, in IT99K-573-1-1 and IT99K-216-44, nodes and leaf area were completely free of CLS lesions. Analysis of variance (Tables 2, 3) showed significant divergences between the generations in all the CLS disease measures. There were significant $(P \leq 0.001)$ differences among the cowpea populations for individual plant reaction to CLS, days to disease incidence, number of infected leaves, and disease severity index (DSI) based on the screening against CLS disease under field condition (Tables 2, 3 ). The susceptible parent, UAM09-1055-6, consistently showed susceptibility to CLS. Differential resistance to the $P$. cruenta had also been reported among cowpea varieties screened for CLS (Booker and Umaharan 2007).

Susceptible parent had an average disease score of 5 at 56 days, while the two resistant parents had a disease score of 0 (Fig. 1a, b). The susceptible and resistant parents also differed for disease score at 63 days, respectively. Within 7 days, the disease score of UAM09 1055-6 increased from 2.8 to 4.5 (Fig. 1c, d) indicating a quick progression of the disease in the susceptible parent, but no change was observed in the resistant parent. This suggests that the resistant parents activated antimicrobial defence compared to the susceptible parent. The resistant parents, IT99K-5731-1 and IT99K-216-44 differed significantly from the susceptible parent, UAM09 1055-6, for all the traits studied for resistance. The results also indicated that the resistance level was higher in the cross UAM09 1055-6 $\times$ IT99K-573-1-1 than in the cross UAM09 1055-6 × IT99K-216-44. The Disease Severity Index (DSI) ratings showed that IT99K-573-1-1 and IT99K216-44 were resistant whereas UAM09 1055-6 was susceptible to CLS (Fig. 1e, f).

Table 2 Analysis of variance of six generations derived from the cross UAM09-1055-6 × IT99K-573-1-1 with respect to various measures of CLS

\begin{tabular}{lrllllll}
\hline SOV & DF & DFF & D_CLS_IN & LESION NO & SEV_7WKS & SEV_8WKS & SEV_9WKS \\
\hline Rep & 3 & $0.4315^{\mathrm{ns}}$ & $5.649^{\mathrm{ns}}$ & $2.805^{\mathrm{ns}}$ & $0.0089^{\mathrm{ns}}$ & $0.0241^{\mathrm{ns}}$ & $0.0427^{\mathrm{ns}}$ \\
Population & 5 & $13.886^{* *}$ & $1433.214^{*}$ & $199.649^{* *}$ & $1.3943^{* *}$ & $4.6057^{* *}$ & $14.004^{* *}$ \\
Error & 15 & 1.1937 & 9.410 & 3.238 & 0.0108 & 0.0370 & 0.0286 \\
Total & 23 & & & & &
\end{tabular}

$D F F$ days to first flower, $D \_C L S \_I N$ days to Cercospora leaf spot disease incidence, $S E V \_7 W K S$ Cercospora leaf spot severity at 7 weeks, $S E V \_8 W K S$ Cercospora leaf spot severity at 8 weeks, SEV_9WKS Cercospora leaf spot severity at 9 weeks

*Significant at 0.05 and **significant at 0.01

Table 3 Analysis of variance of six generations derived from the cross UAM09-1055-6 × IT99K-216-44 with respect to various measures of CLS

\begin{tabular}{lrlllllc}
\hline SOV & DF & DFF & D_CLS_IN & LESION NO & SEV_7WKS & SEV_8WKS & SEV_9WKS \\
\hline Rep & 3 & $2.651^{\mathrm{ns}}$ & $16.585^{\mathrm{ns}}$ & $2.478^{\mathrm{ns}}$ & $0.063^{\mathrm{ns}}$ & $0.071^{\mathrm{ns}}$ & $0.053^{\mathrm{ns}}$ \\
Population & 5 & $17.553^{* *}$ & $1411.292^{* *}$ & $253.765^{* *}$ & $0.0436^{* *}$ & $2.842^{* *}$ & $12.596^{* *}$ \\
Error & 15 & 0.806 & 33.512 & 5.973 & 0.029 & 0.024 & 0.180 \\
Total & 23 & & & & & \\
\hline
\end{tabular}

*Significant at 0.05 and **significant at 0.01

DFF days to first flower, $D \_C L S \_I N$ days to Cercospora leaf spot disease incidence, $S E V \_7 W K S$ Cercospora Leaf Spot severity at 7 weeks, $S E V \_8 W K S$ Cercospora leaf spot severity at 8 weeks, $S E V \_9 W K S$ Cercospora leaf spot severity at 9 weeks 
Fig. 1 Frequency distribution response to Cercospora leaf spot incidence for the different generations of the two crosses. SEV Cercospora leaf spot severity; D_CLS_IN days to Cercospora leaf spot disease incidence a UAM09-1055-6 × IT99K-573-1-1

$$
\square \text { SEV_8WKS }
$$

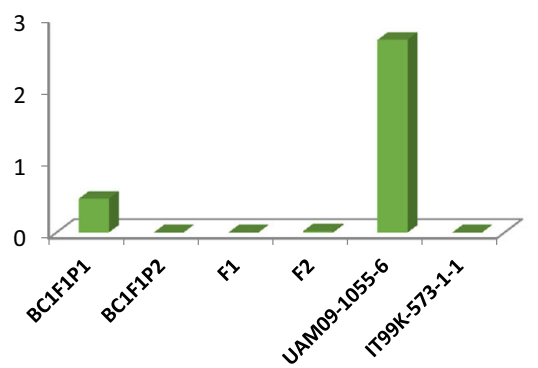

c

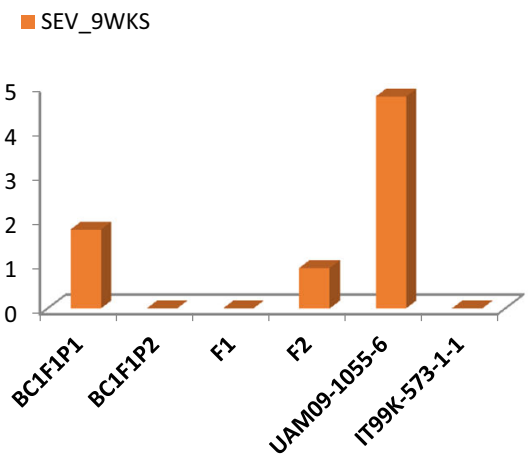

e

$$
\text { D_CLS_IN }
$$

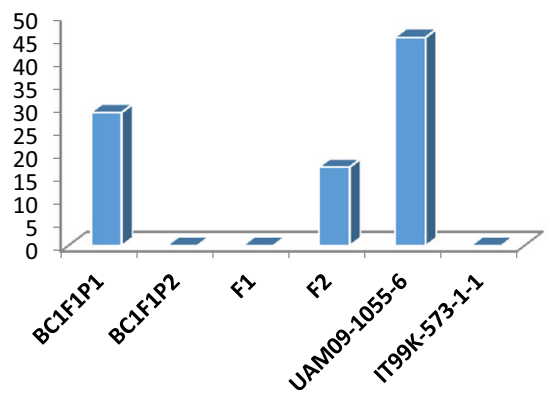

b UAM09-1055-6 × IT99K-216-44

$\because$ SEV_8WKS

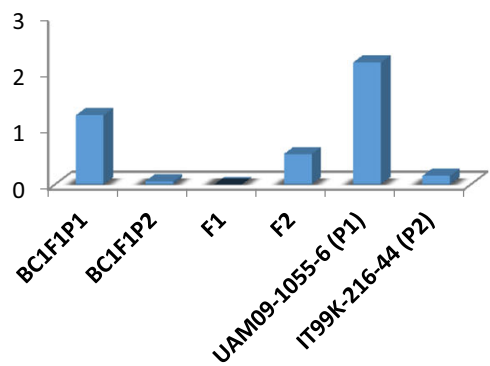

d

SEV_9WKS

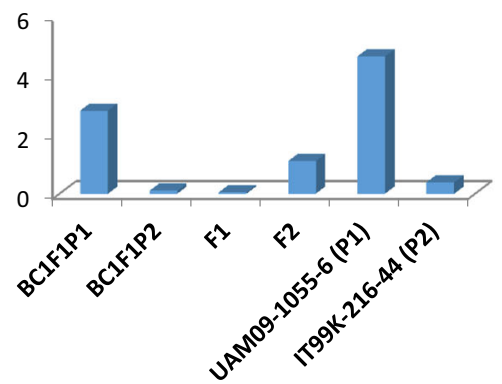

f

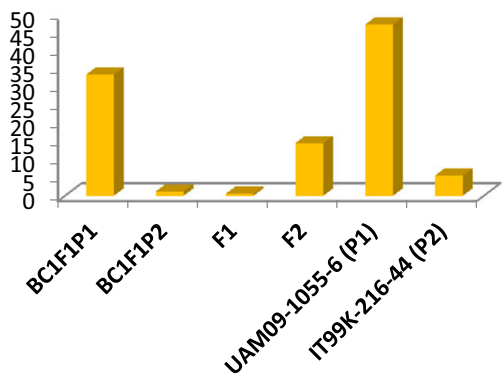

Genetics of CLS resistance

All susceptible/resistant crosses involving either UAM09-1055-6 $\times$ IT99K573-1-1, or UAM09 $1055-6 \times$ IT99K-216-44, produced $F_{1}$ progeny that were resistant to CLS (Table 4). The expression of resistance reaction in $\mathrm{F}_{1}$ generation is an indication of the role of dominant gene in controlling CLS in cowpea. 77 plants of the $F_{2}$ population showed susceptibility to CLS infection while the remaining
222 plants remained resistant by expressing the seedling resistance conferred by the dominant resistance gene and the population followed a monogenic segregation ratio $(P=0.76)$. Similarly, all $\mathrm{F}_{2}$ populations from these crosses segregated in a 3 resistant (insensitive): 1 susceptible (sensitive) ratio. Chi square tests of goodness of fit to genetic ratio showed that the $F_{2}$ population fit a segregation pattern of 3 resistant: 1 susceptible genetic ratio. This segregation ratio further confirmed that a single dominant gene conferred 
Table 4 Segregation (Seg) for reaction to Cercospora leaf spot in the progeny from crosses among resistant cultivars IT99K-573-11, IT99K-216-44 and susceptible cultivars UAM 09-1055-6

\begin{tabular}{|c|c|c|c|c|c|c|c|}
\hline \multirow[t]{2}{*}{ Cross } & \multirow[t]{2}{*}{ Generation } & \multirow[t]{2}{*}{$\begin{array}{l}\text { Total no of } \\
\text { plants }\end{array}$} & \multicolumn{2}{|c|}{$\begin{array}{l}\text { No. of } \\
\text { plants }\end{array}$} & \multirow[t]{2}{*}{$\begin{array}{l}\text { Genetic } \\
\text { ratio }\end{array}$} & \multirow[t]{2}{*}{$\begin{array}{l}\chi^{2}- \\
\text { value }\end{array}$} & \multirow[t]{2}{*}{$\begin{array}{l}\text { Critical } \chi^{2} \text { value } \\
(P<0.05)\end{array}$} \\
\hline & & & $\mathrm{R}$ & $\mathrm{S}$ & & & \\
\hline \multicolumn{8}{|l|}{ Population 1} \\
\hline IT99K-573-1-1 & $\mathrm{P} 1$ & 35 & 35 & 0 & $1: 0$ & & \\
\hline UAM-09-1055-6 & $\mathrm{P} 2$ & 36 & 0 & 36 & $0: 1$ & & \\
\hline UAM-09-1055-6 × IT99K-573-1-1 & $\mathrm{F}_{1}$ & 30 & 30 & 0 & $1: 0$ & & \\
\hline UAM-09-1055-6 × IT99K-573-1-1 & $\mathrm{F}_{2}$ & 299 & 222 & 77 & $3: 1$ & 0.086 & 0.769 \\
\hline $\begin{array}{l}(\mathrm{UAM}-09-1055-6 \times \text { IT99K-573-1- } \\
\text { 1) } \times \text { UAM-09-1055-6 }\end{array}$ & $\mathrm{BC}_{1} \mathrm{P}_{1} \mathrm{~F}_{1}$ & 44 & 22 & 22 & $1: 1$ & 0.01 & 0.920 \\
\hline $\begin{array}{l}(\mathrm{UAM}-09-1055-6 \times \text { IT99K-573-1- } \\
1) \times \text { IT99K-573-1-1 }\end{array}$ & $\mathrm{BC}_{1} \mathrm{P}_{2} \mathrm{~F}_{1}$ & 38 & 38 & 0 & $1: 0$ & - & - \\
\hline \multicolumn{8}{|l|}{ Population 2} \\
\hline IT99K-216-44 & $\mathrm{P} 1$ & 49 & 44 & 5 & $1: 0$ & & \\
\hline UAM-09-1055-6 & $\mathrm{P} 2$ & 23 & 0 & 23 & $0: 1$ & & \\
\hline UAM-09-1055-6 × IT99K-216-44 & $\mathrm{F}_{1}$ & 48 & 47 & 1 & $1: 0$ & & \\
\hline UAM-09-1055-6 × IT99K-216-44 & $\mathrm{F}_{2}$ & 237 & 168 & 69 & $3: 1$ & 2.139 & 0.144 \\
\hline $\begin{array}{l}(\mathrm{UAM}-09-1055-6 \times \text { IT99K-216- } \\
\text { 44) } \times \text { UAM-09-1055-6 }\end{array}$ & $\mathrm{BC}_{1} \mathrm{P}_{1} \mathrm{~F}_{1}$ & 36 & 14 & 22 & $1: 1$ & 1.779 & 0.182 \\
\hline $\begin{array}{l}(\text { UAM-09-1055-6 × IT99K-216- } \\
44) \times \text { IT99K-216-44 }\end{array}$ & $\mathrm{BC}_{1} \mathrm{P}_{2} \mathrm{~F}_{1}$ & 37 & 36 & 1 & $1: 0$ & - & - \\
\hline
\end{tabular}

resistance to CLS in these crosses. Segregation within $25 \mathrm{BC}_{1} \mathrm{P}_{1}$ families derived from resistant $\mathrm{F}_{1}$ and susceptible parents fit a 1:1 (segregating) progeny ratio (Table 4). This segregation pattern further confirmed that resistance to CLS in the genotypes used is conferred by the action of a single dominant resistance gene. The $F_{1}$ data was consistent with this hypothesis as all the $F_{1}$ progenies were completely resistant. This result agrees with the study of Castro et al. (2003), who also reported that resistance to CLS was governed by a single dominant gene in cowpea.

All the susceptible $F_{2}$ derived $F_{3}$ families remained susceptible whereas only 115 out of the 210 resistant $F_{2}$ derived $F_{3}$ families were homozygous for resistance. The remaining 47 families were heterozygous (Table 5) thus distributing the $\mathrm{F}_{2}$ genotypes into 1R:2R:1S monogenic segregation ratio $(P=0.371)$. Similarly, in the second population, all the susceptible $F_{2}$ derived $F_{3}$ families remained susceptible whereas only 57 out of the 220 resistant $F_{2}$ derived $F_{3}$ families were homozygous for resistance. The remaining 118 families were heterozygous thus distributing the $F_{2}$ genotypes into 1R:2R:1S monogenic segregation ratio $(P=0.290)$. Therefore, resistance to CLS is controlled by a single dominant nuclear gene. These results are consistent with a single dominant gene model where the homozygous dominant condition at either of the two loci will confer resistance. This result agrees with the findings of other researchers (Fery et al. 1976; Thakur et al. 2002; Castro et al. 2003; Booker and Umaharan 2007, 2008; Duangsong et al. 2018) who reported a single major dominant gene was responsible for CLS resistance in cowpea and Yardlong bean. Effective selection in early generations of segregating population can be achieved only when additive genetic effects are substantial and heritability is high (Anderson et al. 1991). In the present study, the heritability value for the tested crosses were $97 \%$ for the cross involving UAM09-1055-6 × IT99K-573-11 and $81 \%$ for the cross involving UAM09-1055$6 \times$ IT99K-216-44 indicating that the CLS resistance is a heritable character and the effect of environment on the expression of this trait was small in respect of genetic effect. According to Brule-Babel and Fowler 
Table 5 Segregation for reaction to CLS in $F_{2}$-derived $F_{3}$ families from crosses involving IT99K-573-1-1, IT99K-216-44 and susceptible cultivars UAM 09-1055-6

\begin{tabular}{|c|c|c|c|c|c|c|c|c|}
\hline \multirow[t]{2}{*}{ Cross } & \multirow[t]{2}{*}{ Generation } & \multirow{2}{*}{$\begin{array}{l}\text { Total no } \\
\text { of plants }\end{array}$} & \multicolumn{3}{|c|}{$\mathrm{F}_{2}$-derived $\mathrm{F}_{3}$ families } & \multirow{2}{*}{$\begin{array}{l}\text { Genetic } \\
\text { ratio }\end{array}$} & \multirow{2}{*}{$\begin{array}{l}\chi^{2}- \\
\text { value }\end{array}$} & \multirow{2}{*}{$\begin{array}{l}\text { Critical } \chi^{2} \\
\text { value } \\
(P<0.05)\end{array}$} \\
\hline & & & $\begin{array}{l}\text { Homozygous } \\
\text { resistant }\end{array}$ & Segregating & $\begin{array}{l}\text { Homozygous } \\
\text { susceptible }\end{array}$ & & & \\
\hline $\begin{array}{l}\text { UAM-09-1055- } \\
6 \times \text { IT99K-573-1- } \\
1\end{array}$ & $\mathrm{~F}_{3}$ & 210 & 48 & 115 & 47 & $1: 2: 1$ & 1.9817 & 0.371 \\
\hline $\begin{array}{l}\text { UAM-09-1055- } \\
6 \times \text { IT99K-216- } \\
44\end{array}$ & $\mathrm{~F}_{3}$ & 220 & 57 & 118 & 45 & $1: 2: 1$ & 2.4726 & 0.290 \\
\hline
\end{tabular}

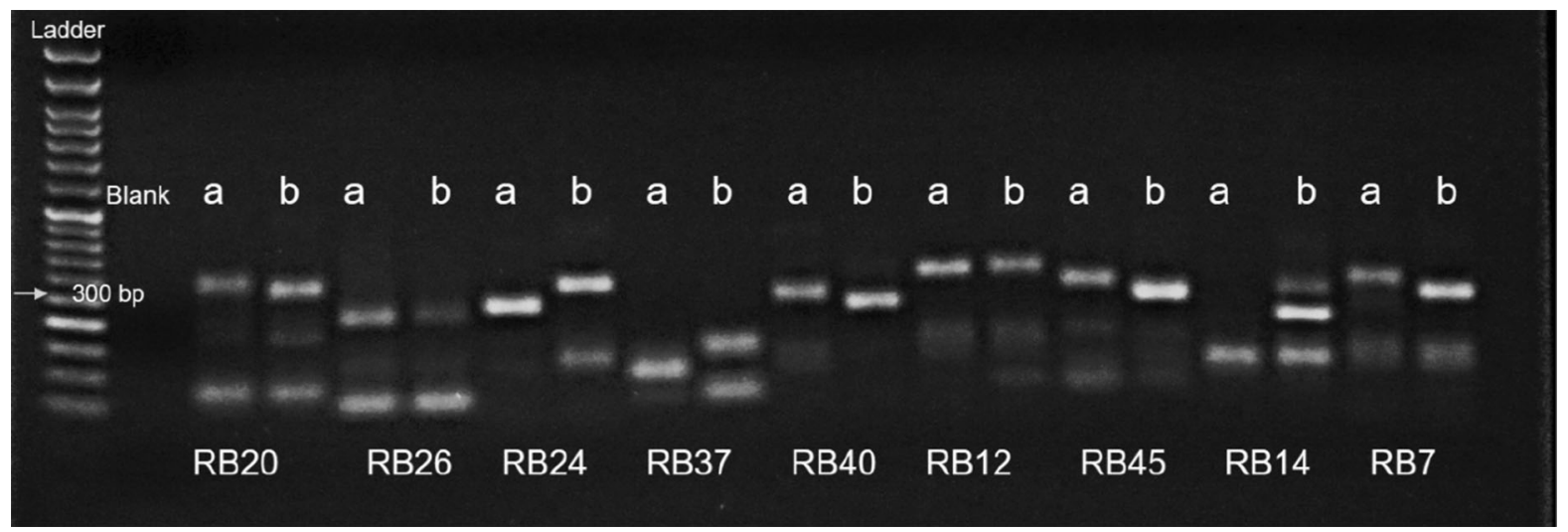

Fig. 2 Gel image showing DNA bands from amplification products of SSR markers screening for Cercospora leaf sport resistance. The PCR products were resolved using 2\% Agarose

(1988) low heritability estimates are largely associated with narrow crosses, while intermediate to high heritability estimates are associated with wider crosses. This knowledge corresponds with the results of our study, because the used parents were quite different in reaction to CLS resistance.

\section{Marker screening for CLS resistance}

Based on our screening of cowpea SSRs which are available on the CGKB database, we identified a set of promising cowpea SSR primer pairs and tested them for their co-segregation with CLS (Fig. 2). Microsatelites have been identified in Vigna species based on database searches (Yu et al. 1999) and microsatellites libraries have been specifically developed from cowpea ( $\mathrm{Li}$ and Nelson 2001). Thirty-five SSR markers were screened with the contrasting bulks that were made from individuals of a susceptible and gel stained with ethidium bromide. Different primer combinations screened with a UAM09 1055-6 susceptible, b IT99K-5731-1 resistant cultivarto identify linked markers

resistant plants Out of which nine primer pairs RB20, RB26, RB24, RB37, RB40, RB12, RB45, RB14, RB7 $(25.71 \%)$ showed polymorphisms between parents and the bulks (Fig. 2). Among the nine promising primer pairs, one marker, RB24 (Forward; 5'-GTC AAAGCAATGGACTAA-3', Reverse; 5'TGAATTT GATACACACACTACT- $3^{\prime}$ ) with annealing temperature of $60{ }^{\circ} \mathrm{C}$ was found to be useful. The marker consistently showed polymorphic band between the two parents. Ten randomly selected samples were taken from the resistant and susceptible plants to prepare bulks for bulk segregant analysis (Fig. 2). The marker was found to distinguish between resistant and susceptible CLS locus. This polymorphic SSR marker was further analysed on the $299 \mathrm{~F}_{2}$ plants for linkage analysis with the CLS locus. The marker RB24 was associated with the CLS locus and was located at a genetic distance of $5.2 \mathrm{cM}$ from phenotypic variation. The RB24 resistance allele amplified a $291 \mathrm{bp}$ 


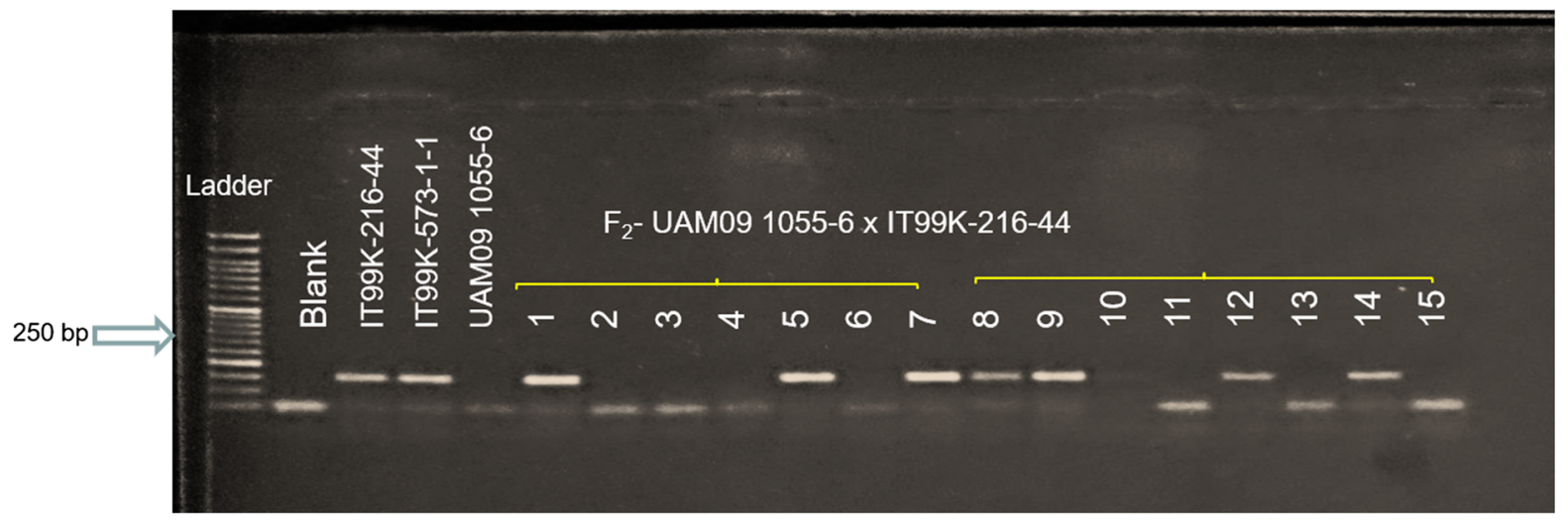

Fig. 3 Gel image showing DNA bands from amplification products of RB24 SSR primer for parents and respective F2 progenies. The PCR products were resolved on 2\% Agarose gel stained with ethidium bromide. The presence of a $250 \mathrm{bp}$ indicates the presence of the resistance gene marker, while the absence indicates susceptibility

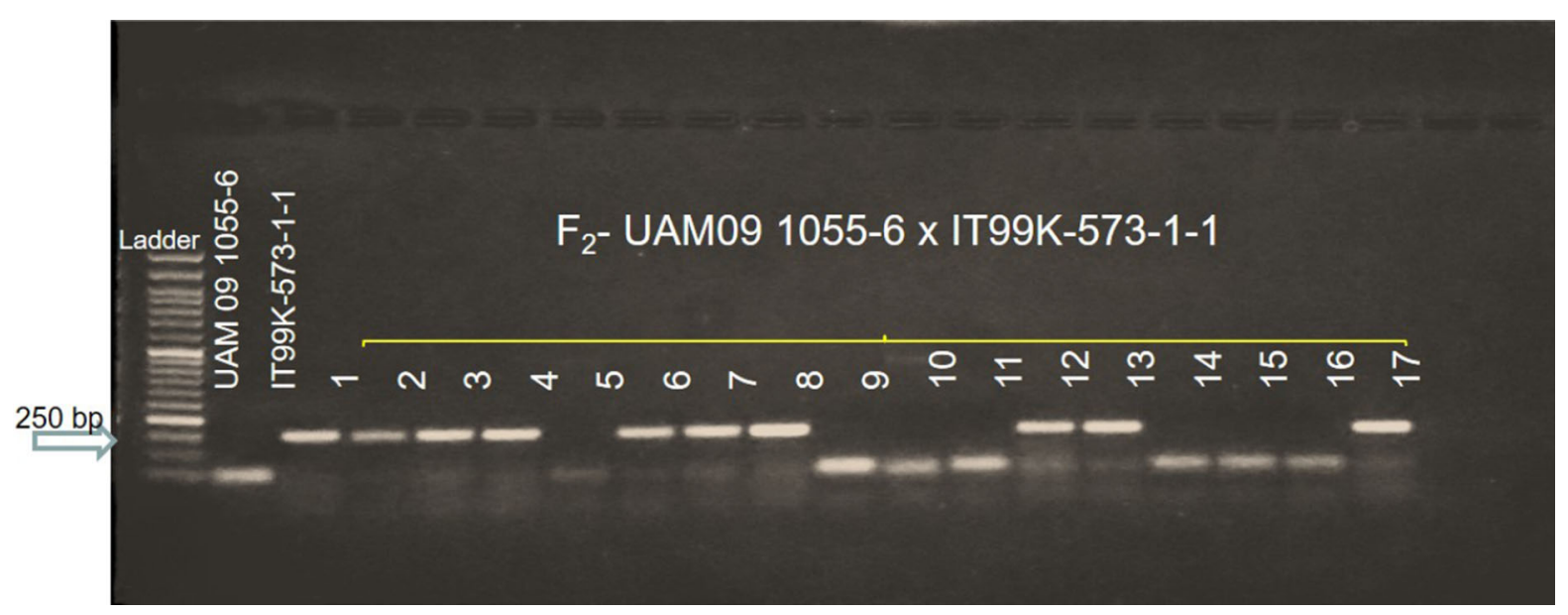

Fig. 4 Gel image showing DNA bands from amplification products of SSR for improved lines and their respective parents. The PCR products were resolved on $2 \%$ Agarose gel stained

fragment and the CLS susceptible allele linked marker amplified a 250 bp fragment (Figs. 3, 4). The marker results further support the phenotypic screening to identify the difference between the cultivars, relative to resistance and susceptibility to CLS. Validation of this SSR linked marker in this study is an advancement in breeding efforts to develop and deploy molecular marker for future use in marker-assisted selection (MAS), which can shorten the breeding cycle for CLS resistance in cowpea cultivars. This marker will also help to improve precision in discrimination of resistant and susceptible cultivars when screening large parental genotypes for CLS in cowpea breeding with ethidium bromide. The presence of a $250 \mathrm{bp}$ indicates the presence of the resistant allele

programme. The use of marker assisted breeding methods will improve the efficiency of screening for resistant traits and effectiveness of incorporating the major resistance genes or pyramiding resistant genes. This study provides the basis for exploitation of markers for CLS in cowpea breeding program.

\section{Conclusions}

The SSR marker reported in this study will be useful for breeding purpose since it differentiates the presence of the gene in homozygous and heterozygous 
resistant plants (figure). It has been suggested that the marker should be within $10 \mathrm{cM}$ of the gene of interest for effective marker-assisted selection breeding (Cheng et al. 1998). The marker, RB24 mapped a distance of $5.2 \mathrm{cM}$, will therefore be especially useful for those breeding programmes in cowpea where pyramiding is performed to stack more than one resistant gene into a single background. In agreement with other studies, the findings from our research confirms that a single dominant gene confers resistance to CLS in cowpea. The breeding implication is that breeding programs can easily incorporate resistant gene(s) to CLS susceptible cultivars with any selection method to address CLS problem. The single dominant gene possessed by IT99K-573-1-1 and IT99K-216-6 indicates that these cultivars are promising parental donors to improve CLS resistance in cowpea cultivars due to easy of introgression of major genes. Also, the RB24 primer validated in the $F_{2}$ population in this study may be valuable in marker-assisted selection (MAS) for CLS resistance breeding. Our research provides the first evidence of inheritance of CLS resistance among Nigeria cowpea germplasm.

Acknowledgements This work was funded by the Kirkhouse Trust (Grant No. 001), UK from the grants awarded to the University of Agriculture, Makurdi through the project 'Genetic Improvement of cowpea for Striga resistance using molecular tools in Nigeria. The Technical assistance of Ms. Deborah F. Ayeni is gracefully acknowledged.

\section{Compliance with ethical standards}

Conflict of interest The authors declare that there is no conflict of interest.

Open Access This article is distributed under the terms of the Creative Commons Attribution 4.0 International License (http:// creativecommons.org/licenses/by/4.0/), which permits unrestricted use, distribution, and reproduction in any medium, provided you give appropriate credit to the original author(s) and the source, provide a link to the Creative Commons license, and indicate if changes were made.

\section{References}

Allen DJ (1983) The pathology of tropical legumes. Wiley, Chichester

Allen DJ, Lenne JM (1998) Diseases and constraints to production of legumes in agriculture. In: Allen DJ, Lenne JM (eds) The pathology of food and pasture legumes. CAB International, Wallingford, pp 1-6
Anderson WF, Holbrook CC, Wynne JC (1991) Heritability and early-generation selection for resistance to early and late leaf spot in peanut. Crop Sci 31:588-593

Booker HM, Umaharan P (2007) Identification of resistance to cercospoara leaf spot of cowpea. Eur J Plant Pathol 118:401-410

Booker HM, Umaharan P (2008) Quantitative resistance to Cercospora leaf spot disease cause by Pseudocercosporacruenta in cowpea. Euphytica 162:167-177

Boukar O, Kong L, Singh BB, Mudock L, Ohm HW (2004) AFLP and AFLP-derived SCAR markers associated with Striga gesnerioides resistance in cowpea. Crop Sci 44(4):1259-1264

Brule-Babel AL, Fowler DB (1988) Genetic control of cold hardiness and vernalization requirement in winter wheat. Crop Sci 28(6):879-884. https://doi.org/10.2135/ cropsci 1988

Castro NR, Menezes GC, Coelho RSB (2003) Inheritance of the genetic resistance of caupi to Cercosporiose. Fitopathology 28(5):552-554

Cheng FS, Weeden NF, Brown SK, Aldwinckle HS, Gardiner SE (1998) Development of a DNA marker for Vm, a gene conferring resistance to apple scab. Genome 41:208-214

Diouf D, Hilu KW (2005) Microsatellites and RAPD markers to study genetic relationships among cowpea breeding lines and local varieties in Senegal. Genet Resour Crop Evol 52(8):1057-1062

Duangsong U, Laosatit K, Somta P, Srinives P (2018) Genetics of resistance to Cercospora leaf spot disease caused by Cercospora canescens and Psuedocercospora cruenta in yardlong bean (Vigna unguiculata ssp. sesquipedalis) $\times$ grain cowpea (V. unguiculata ssp. unguiculata) populations. J Genet 97(5):1451-1456

FAOStat (2017) FAOSTAT, statistical data base. Food and Agricultural Organizations of the United Nations, Rome. Visited on 15/08/2017

Fery RL, Dukes PD, Cuthbert FP Jr (1976) The inheritance of Cercospora leaf spot resistance in Southern pea (Vigna unguiculate (L.) Walp.). J Hortic Sci 101:148-149

Hart RO (1977) Etiology of Cercospora cruenta Sacc. on Vigna unguiculata (L.) Walp. M.Sc. Thesis. The University of Guyana, Turkeyen, E.C.D. Guyana

Kimber RBE, Paull J (2011) Identification and genetics of resistance to cercospora leaf spot (Cercospora zonata) in faba bean (Vicia faba). Euphytica 177(3):419-429. https:// doi.org/10.1007/s10681-010-0288-7

Li Z, Nelson RL (2001) Genetic diversity among soybean accessions from three countries measured by RAPD. Crop Sci 41:1337-1347

Mukesh KM, Tiwari S, Choudhary R, Kalrsliya SS, Nasnwa R (2017) Efficacy of some botanicals against leaf spot of Mung bean (Vigna radiata L.) caused by Cercospora canescens. Int J Adv Bio Res ABR 7(2):309-311

Mulder JL, Holliday P (1975a) Cercosporacanescens. CMI descriptions of pathogenic fungi and bacteria No. 462. The Commonwealth Mycological Institute, Kew, Surrey

Ogunkanmi L, Ogundipe O, Ng N, Fatokun C (2008) Genetic diversity in wild relatives of cowpea (Vigna unguiculata) as revealed by simple sequence repeats (SSR) markers. J Food Agric Environ 6(3\&4):263-268 
Oladiran AO, Oso BA (1983) Comparative susceptibility of some cowpea lines to brown blotch. Trop Grain Legume Bull 28:10-17

Omoigui LO, Yeye M, Ousmane B, Gowda BS, Timko MP (2012) Molecular characterization of cowpea breeding lines for Striga resistance using SCAR markers. J Agric Sci Technol B 2:362-376

Omoigui LO, Danmaigona CC, Kamara AY, Ekefan E, Timko MP (2018) Genetic analysis of Fusarium wilt resistance in cowpea (Vigna unguiculata Walp.). Plant Breed. https:// doi.org/10.1111/pbr. 12628

Ouedraogo TJ, Maheshwari V, Berner DK, Stpierre CA, Belzile F, Timko MP (2001) Identification of AFLP markers linked to resistance of cowpea (Vigna unguiculate L.) to parasitism by Striga gesnerioides. Theor Appl Genet 102:1029-1036

Ouedraogo JT, Gwoda BS, Jean M, Close TJ (2002) An improved genetic linkage map for cowpea (Vigna unguculata L.) Combining AFLP, RFLP, resistance traits. Genome 45(1):175-188

Pasupuleti J, Venuprasad R, Rathore A, Upakula A, Reddy RK, Waliyar F, Nigam SN (2013) Genetic analysis of resistance to late leaf spot in interspecific groundnuts. Euphytica. https://doi.org/10.1007/s10681-013-0881-7

Poehlman JM (1991) The Mungbean. Oxford and IBH Publishing Co. PVT. Ltd., New Delhi, p 375

Pottorff M, Wanamake S, Ma YQ, Ehlers JD, Roberts PA, Close TJ (2012) Genetic and physical mapping of candidate genes for resistance to Fusarium oxysporum f.sp. tracheiphilum race 3 in cowpea [Vigna unguiculata (L.) Walp]. PLoS ONE 7(7):e41600. https://doi.org/10.1371/ journal.pone

SAS Institute (2014) The SAS system for Windows. v. 9.3. SAS Inst., Cary

Schneider RW, Williams RJ, Sinclair JB (1976) Cercospora leaf spot of cowpea: models for estimating yield loss. Phytopathology 66:384-388

Shoba D, Manivannan NP, Vindhiyavarman P, Nigam SN (2012) SSR markers associated for late leaf spot disease resistance by bulked segregant analysis in groundnut
(Arachis hypogaea L.). Euphytica. https://doi.org/10.1007/ s10681-012-0718-9

Singh B, Ajeigbe HA, Tarawali SA, Ferdinez-Rivera S, Abubakar M (2003) Improving the production and utilization of cowpea as food and fodder. Field Crops Res 84:169-170

Tarawali SA, Singh BB, Gupta SC, Tabo R, Harris F, Nokoe S, Fernández-Rivera S, Bationo A, Manyong VM, Makinde $\mathrm{K}$, Odion EC (2002) Cowpea as a key factor for a new approach to integrated crop-livestock systems research in the dry savannas of West Africa. In: Fatokun CA, Tarawali S, Singh BB, Kormawa PM, Tamo M (eds) Challenges and opportunities forenhancing sustainable cowpea production. International Institute of Tropical Agriculture, Ibadan, pp 233-251

Thakur RP, Patel PN, Verma JP (2002) Genetical relationships between reactions to bacterial leaf spot, yellow mosaic and Cercospora leaf spot in mungbean (Vignaradiata). Euphytica 26:765-774

Timko MP, Gowda BS, Ouedraogo J, Ousmane B (2008) Molecular markers for analysis of resistance to Striga gesnerioides in cowpea. In: Ejeta G, Gressell J (eds) Integrating new technologies for Striga control: towards ending the witch-hunt. World Scientific, Singapore

Warner NJ (1952) A method for estimating heritability. Agron J 44:427-430

Yu K, Park SJ, Poysa V (1999) Abundance and variation of micro-satellite DNA sequences in beans (Phaseolus and Vigna). Genome 42:27-34

Zongo A, Khera P, Sawadogo M, Shasidhar Y, Sriswathi M, Vishwakarma SM, Sankara P, Ntare B, Varshney RK, Pandey MK, Desmae H (2017) SSR markers associated to early leaf spot disease resistance through selective genotyping and single marker analysis in groundnut (Arachis hypogaea L.). Biotechnol Rep (Amst). https://doi.org/10. 1016/j.btre.2017.07.005

Publisher's Note Springer Nature remains neutral with regard to jurisdictional claims in published maps and institutional affiliations. 